aircraft methods of locust control. Both fundamental problems of locust physiology, behaviour, etc., and the problems of control are in the programme. Workers interested in such problems and heads of university departments who may be able to offer laboratory facilities are invited to write to the Director of the Centre, British Museum (Natural History), London, S.W.7.

\section{Accommodation for Scientific Workers in Danish Laboratories}

THE Proparatory Commission of the United Nations Educational, Scientific and Cultural Organisation. 47 Belgrave Square, London, S.W.I, has reeeived from Denmark an offer to accommodate free of charge up to two hundred graduate scientific workers from war-devastated countries in Danish laboratories and technical colleges. The invitation, which is not open to students, applies particularly to graduate scientific workers who, due to the effects of war, are unable to obtain the requisite laboratory facilities in their own countries, whether in Europe, the United Kingdom, China, the Philippines or Iran. All tuition and laboratory fees will be waived for a period up to two years. Travel and living expenses are expected to be met by the visitors' government. In exceptional cases the Danish authorities will consider defraying these expenses also. On a reasonable scale a single person can live for about $\mathrm{Kr} .5,000$ (about $£ 250$ ) a year in Denmark. The scheme is being sponsored by the Danish Committee for the Training of Foreign Scientists in Danish Laboratories.

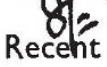

AN earthquake with probable epicentre in the Strait of Georgia 20 miles west of the City of Vancouver and 100 me severity shook central districts of Vancg fyland on June 23. Buildings, especially in thool sth and west of Vancouver Island, swayed consiburably and some chimneys collapsed. The depth of water in lakes in the interior of Vancouver Island and also the depths of water along the eastern coast of the Island changed considerably. Several beaches became submerged to a depth of $100 \mathrm{ft}$., and the Canadian Hydrographic Department has ordered the taking of new soundings in the strait for navigational purposes. Dr. E. A. Hodgson has pointed out that there was no immediate aftershock to this earthquake. The earthquake was registered on the seismographs in Switzerland, preliminary pulses arriving at Zurich at $17 \mathrm{~h} .25 \mathrm{~m} .05 \cdot 2 \mathrm{~s}$. G.M.T. They were also recorded at Toledo in Spain at $17 \mathrm{~h}$. 25m. 13s. G.M.T.

On July 1 an earthquake originated near Fairbanks, Alaska (U.S. Coast and Geodetic Survey), and on July 18 an earthquake at 6 h. $07: \mathrm{lm}$. G.M.T. with aftershock at $7 \mathrm{~h} .16 \cdot 5 \mathrm{~m}$. G.M.T. had their epicentres at lat. $50^{\circ} \mathrm{N}$., long. $129^{\circ} \mathrm{W}$., which is in the Pacific Ocean just off Cape Cook (north-west Vancouver Island) and north-west of the earthquake of June 23. The epicentre of the July 18 shock was determined by the U.S. Coast and Geodetic Survey in co-operation with Science Service and the Jesuit Seismological Association from instrumental readings from fifteen observatories. The depth of focus was estimated to have been rather less than $100 \mathrm{~km}$., which is deeper than normal.

The slight earth tremor which was felt at Leyland in Lancashire about 7 a.m. B.S.T. on July 21 is now believed to have been caused by an explosion in a
$100 \mathrm{ft}$. borehole. Prospecting for oil by seismic means was proceeding. The effect at Leyland was greater than expected for a normal shot.

On August 4 an earthquake of considerable severity originated in the Atlantic Deep, north-west of Puerto Rico. Severe shocks were felt at Puerto Rico, Trinidad, and Ciudad Trujillo on Haiti, and high waves swept into the ports of Matanzas, Puerto Plata, and Ciudad Trujillo. The docks and some ancient churches in this latter city were slightly damaged, and the telephone service was temporarily interrupted at Puerto Rico; but considering the energy of the shock as registered on seismograms throughout the world, surprisingly little damage was done in towns near the epicentre. Strong aftershocks of the earthquake continued at intervals for a week.

\section{Flight Research Section of the Canadian National Research Council}

A Fuight 7 menarch Section of the Division of Mechanica/ Engineering of the National Research Council is being set up at the Royal Canadian Air Forcestation at Arnprior, Ontario. This Section will be fnanced and operated by the National Research Council. The aerodrome will remain the property of the Department of National Defence for Air, but is leased to the Research Council. The R.C.A.F. will supply flying personnel, aircraft and maintenance staff. Research activities will be under the direction of the National Research Council. It will be a small establishment with probably not more than a hundred men and five aircraft. It is to contain a nucleus of trained flight research personnel and equipment, the object being to do basic research without the interference of normal air traffic. In the laboratories of the Division of Mechanical Engineering of the National Research Council near Ottawa three wind tunnelstwo horizontal and one vertical-provide excellent facilities for studies on models of aircraft to determine the probable performance of full-scale aircraft in flight. The Flight Research Section will provide the means of securing necessary additional information to supplement and amplify the results obtained on model tests in the wind tunnel.

\section{Scientific Work in Germany}

Dr. H. Zalmus, of the Galton Laboratory, University College, London, W.C.1, has received the following information from the French zone of occupgtion of Germany, in a letter from Prof. Alfrød Kühn. Prof. Alfred Kühn left the Zoological Institute in Göttingen in 1937 and went to the Kaiser-Wilhelm Institut für Biologie in Berlin. In the autumn of 1943 he was able to evacuate his department from there to Hechingen, Hohenzollern, and thus all his apparatus and library have been saved. Work in this institution has continued since the occupation first by the Americans and then by the French under the protection of the American T-force and the Mission Scientifique. In December 1945, Prof. Kühn was appointed to the chair of zoology in the University of Tübingen in the French zone of occupation, and he is now trying to move the other biological departments of the KaiserWilhelm Institute to Tübingen. A botanical department under Melchers, working on plant hormones and plant viruses, has provisional quarters in the botanical department of the University. Hartmann and Bauer are working in Hechingen, Hohenzollern, and Hämmerling in Langenargen am Bodensee in 
the Institute for Limnology. Prof. Kühn has lost all his close collaborators and is training young workers. His main interest at present is the chemical action of genes; in this work he is collaborating with Prof. Butenandt, who occupies the chair of physiological chemistry in Tübingen.

\section{Study of Photo-elasticity}

IT has been suggested that a society or association should be formed in Great Britain for men of science and engineers who are interested in the development and applications of photo-elasticity. Such an organisation would enable research workers in this field to keep in touch with each other and, in particular, would provide a common meeting ground for workers in industrial, government and university laboratories. Messrs. H. T. Jessop (Engineering Department, University College, Gower Street, London, W.C.1) and F. K. Frankl (Cambridge University Engineering Department, Trumpington Street, Cambridge) state that it is proposed to arrange a meeting on September 6 at 11 a.m. at University College, London, at which the general character and aims of such a society could be discussed. Communications about the meeting should be sent to Mr. Frankl at the address given above.

\section{Association of Special Libraries and Information Bureaux: Annual Conference}

THE twenty-first conference of the Association of Special Libraries and Information Bureaux will be held at the Polytechnic, Regent Street, London, W.1, during September 13-15, and a provisional programme has been issued. The presidential address, by Sir Reginald Stradling, will be given on September 14, and the subject is "Special Libraries in Research Organisations". Papers have been promised on the preparation of critical bibliographies (A. D. Roberts, British Library of Political and Economic Science), communication of specialist information to business executives (Prof. R. S. Hutton), mathematical machines and tables (Dr. L. J. Comrie, Scientific Computing Service, Ltd.), and technical dictionaries and glossaries (Miss M. Gosset, Science Library). A symposium on aspects of documentation in Europe has been arranged for September 15 (morning session), at which Mrs. Lancaster-Jones (British Council) will deal with the European demand for British scientific literature, Miss Esther Simpson will speak on the Society for Visiting Scientists, and Ronald Fraser (Control Commission for Germany and Austria) on Germany; information services in other European countries will also be surveyed. Further particulars of the conference can be obtained from the Association of Special Libraries and Information Bureaux, 52 Bloomsbury Street, London, W.C.1.

\section{University of/London Appointments}

THE following appointments in the University of London have been announced: Dr. S. E. Hollingworth, a senior geologist in H.M. Geological Survey, to the Yates-Goldsmid chair of geology tenable at University College, as from October 1; and Dr. Ronald Hare, of the Connaught Laboratories, University of Toronto, to the University chair of bacteriology tenable at St. Thomas's Hospital Medical School, as from October 1.

The following titles, in respect of the posts indicated, have been conferred: Mr. W. R. Spurrell, Guy's
Hospital Medical School, to be professor of physiology in the university; Dr. L. E. Bayliss, University College, to be reader in physiology in the University ; Dr. S. J. De Navasquez, Guy's Hospital Medical School, to be reader in pathology in the University; Dr. R. W. B. Pearce, Imperial College of Science and Technology, to be reader in spectroscopy in the University; Dr. R. J. V. Pulvertaft, Westminster Hospital Medical School, to be professor of clinical pathology in the University; Dr. W. D. Wright, Imperial College of Science and Technology, to be reader in colour vision in the University; Dr. C. E. Wynn-Williams, Imperial College of Science and Technology, to be reader in physics in the University.

Karel Preis (1846-1916)

ALthough not widely known outside Central Europe, Karel Preis contributed to the advance of two scien qu funded a sugar research station and a now foffows technical museum. His parents were French probably settling in Bohemia as young rofuges during the Napoleonic wars. At one time hif Aather had a wine business in Prague, where Karel was born on August 20, 1846. After studying chem. istry and other sciences at the Polytechnic, Preis was eventually made a professor there in 1868. In his small analytical laboratory he engaged upon a series of minor researches, and one of his earliest discoveries related to a double sulphide of iron and potassium, $\mathrm{K}_{2} \mathrm{~S}, \mathrm{FeS}$, which he made by heating sulphur, reduced iron and potassium carbonate together to bright redness. Ten years later (1879), together with B. Rayman, he studied the action of nitric acid on cholesterol and cholesteryl chloride, and in 1884 they prepared and examined the bromides of tin. They isolated a number of derivatives and studied the reactions of the tin halides with water, ammonia and other substances. In addition to these researches, Preis wrote a number of text. books and trained many successful technical chemists, particularly for the sugar industry. He was editor of the Chemické Listy for twenty years and of the sugar journal, Listy Cukrovarnické, for thirty-three years. Moreover, Preis was a keen naturalist and collector of insects; he wrote a monograph on Czech Hymen. optera.

\section{Announcements}

Prof. Arthur Holmes, regius professor of geology in the University of Edinburgh, has been elected a corresponding member of the Geological Society of Bolgium, in recognition of his important contributions to geological science.

Prof. H. S. RAPER, since 1923 Brackenbury professor $/ 1$ physiology and director of the Physiological Laboratories in the University of Manchester, has been appointed dean of the Medical School and professor of chemical physiology in the University. Dr. W. Schlapp, reader in experimental physiology and assistant director of the Physiological Laboratories, has been appointed to the Brackenbury chair and to the directorship of the Physiological Laboratories.

Erratuy. The ordinates of the graph accompanying the communication entitled "Effect of $p \mathrm{H}$ in the Dye Titration of Vitamin C in Certain Plant Matprials" by Dr. F. Wokes in Nature of July 27, p. 133 , should read " $100,75,50,25$ " and not " 10 , $7,5,2$ " as printed. 